\title{
JOVENS E VULNERÁVEIS: um estudo sobre a exclusão social entre os jovens de Santa Maria - DF Marcelo Staciarini Puttini
}

Curso: Mestrado em Sociologia

Data de defesa da dissertação: 30 março de 2004

Orientador: Prof. Dr. Elimar Pinheiro do Nascimento

\section{Resumo}

O presente trabalho tem como tema central a juventude e a maneira como esta sofre e enfrenta as consequiências da exclusão social, em suas diferentes formas de apresentação. O terreno de pesquisa é a cidade-satélite de Santa Maria, uma das mais pobres do Distrito Federal, apresentando, assim, precárias condições de habitação e infra-estrutura básica e social.

Em primeiro lugar, tentaremos compreender como o tratamento conceitual do tema juventude pode contribuir para a compreensão dos processos sociais. Em seguida, serão abordados as formas e os processos de compreensão da exclusão social, especialmente, quanto a suas relações específicas com o universo dos jovens pobres e urbanos. Segue-se a análise da pesquisa de campo, que busca compreender os processos de exclusão e vulnerabilidade social a partir dos planos de inserção e socialização juvenil, dando especial destaque para o contexto familiar e para as relações de precariedade e vulnerabilidade desses jovens diante do mundo do trabalho.

Abordam-se, ainda, a formação educacional e as aspirações destes jovens quanto ao futuro, visando demonstrar os mecanismos de diferenciação e formação de identidade, próprios de seu universo. Depois disso, é abordado o universo dos grupos de convívio juvenil, os processos de formação da subjetividade e a inserção no mercado de consumo. 
Finalmente, avaliam-se as formas de manifestação e as representações desses jovens perante as vulnerabilidades impostas pela realidade vivida.

Palavras-chave: jovem; juventude; socialização; diferenciação; exclusão social; vulnerabilidade social. 